\title{
Biology and Control of Sedges Associated with Sugarcane and Rice in Florida ${ }^{1}$
}

\author{
A. R. Calderon and D. C. Odero ${ }^{2}$
}

Sugarcane (Saccharum spp. interspecific hybrids) is an important crop cultivated on organic soils in the Everglades Agricultural Area (EAA) and surrounding mineral soils in southern Florida. Florida is a leading producer of sugarcane in the United States with an average of 400,000 acres of production over the last two decades (VanWeelden et al. 2020). The sugarcane crop in Florida is cultivated in rotation with several crops, including rice (Oryza sativa L.), during the sugarcane fallow renovation period. Rice cultivated on approximately 25,000 acres, mainly on organic soils in the EAA, provides income to growers and also provides important ecosystem services, including soil health improvement and reduction of soil subsidence or soil loss due to oxidation (Bhadha et al. 2020). Flooded rice fields also negatively influence populations of corn wireworm (Melanotus communis), an important insect pest of sugarcane in the region (Cherry 2017). In Florida, sugarcane is vegetatively propagated by planting stalk sections while rice is drill-seeded. Several weed species such as broadleaves, grasses, and sedges infest Florida sugarcane and rice fields. Sedges are among the most common and troublesome weeds associated with sugarcane and rice production in Florida (Rott et al. 2018; Webster 2012).
After planting, sedges can emerge prior to crop emergence or at any time during the sugarcane growing season.

Sedges are grass-like plants with parallel leaf venation and aerial flower-bearing stems in the family Cyperaceae composed of approximately 3,000 species, with roughly 220 species considered as weeds (Bendixen and Nandihalli 1987). A majority of these sedge species in crops such as sugarcane and rice are in the genus Cyperus (Etheredge et al. 2010). The most common and problematic sedges found in Florida sugarcane and rice are purple nutsedge and yellow nutsedge, with the latter being the most prevalent. These two species may be found growing together in fields and are difficult to distinguish if flowers are absent. They are common in sugarcane and rice in Florida due to their ability to tolerate a wide range of soil types, wet soils, and poorly drained soils, and their ability to grow under flooded rice conditions. Less problematic sedges found in these cropping systems include annual sedge, flatsedge, and rice flatsedge. This article describes the biology and control options for sedges associated with sugarcane and rice in Florida to assist growers in making correct identification and appropriate management decisions to help control these species.

1. This document is SS-AGR-455, one of a series of the Agronomy Department, UF/IFAS Extension. Original publication date June 2021. Visit the EDIS website at https://edis.ifas.ufl.edu for the currently supported version of this publication.

2. A. R. Calderon, graduate student, Agronomy Department; and D. C. Odero, associate professor, Agronomy Department; UF/IFAS Everglades Research and Education Center, Belle Glade, FL 33430.

The use of trade names in this publication is solely for the purpose of providing specific information. UF/IFAS does not guarantee or warranty the products named, and references to them in this publication do not signify our approval to the exclusion of other products of suitable composition.

All chemicals should be used in accordance with directions on the manufacturer's label.

Use pesticides safely. Read and follow directions on the manufacturer's label.

The Institute of Food and Agricultural Sciences (IFAS) is an Equal Opportunity Institution authorized to provide research, educational information and other services

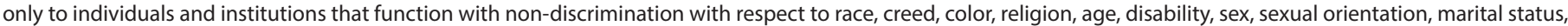

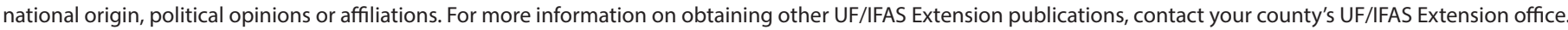
U.S. Department of Agriculture, UF/IFAS Extension Service, University of Florida, IFAS, Florida A \& M University Cooperative Extension Program, and Boards of County Commissioners Cooperating. Nick T. Place, dean for UF/IFAS Extension. 


\section{Purple Nutsedge}

Purple nutsedge (Cyperus rotundus L.) is a herbaceous perennial weed native to Eurasia (Bryson and DeFelice 2009). In the continental United States, it is found in Texas to Virginia, Maryland, Delaware, Pennsylvania, and New Jersey, and in Arizona, California, and Oregon (Murphy et al. 2013; USDA 2020b). Purple nutsedge is found throughout Florida from the Panhandle to the Keys (USDA 2020b). The distribution of purple nutsedge is limited by low temperature and moisture (Bendixen and Nandihalli 1987), which are not limiting environmental factors in southern Florida where sugarcane and rice are cultivated.

\section{Biology and Life Cycle}

Purple nutsedge is a rapidly spreading sedge with tubers and underground runners or rhizomes. Seedlings of purple nutsedge are inconspicuous and rare to find because the plant spreads almost exclusively via rhizomes and tubers (Stoller and Sweet 1987). The leaves are shiny, dark green, linear, flat or slightly corrugated, approximately $1 / 16$ inch to $1 / 4$ inch wide and 6 to 12 inches long with a prominent midvein, and formed in groups of three (i.e., three-ranked). The leaves abruptly taper to a sharp point at the tip and are often described as "boat-shaped" (Figure 1). The stem is triangular, smooth, solitary, and 4 inches to 6 inches tall. Purple nutsedge has reddish-purple to reddish-brown flowers formed at the end of stems and 2 to 4 leaflike bracts below the flowers (Figure 2). Although flowers sometimes develop into mature viable seeds, propagation is primarily by rough, irregularly shaped tubers connected by wiry rhizomes which are underground stems (Figure 3 ). Purple nutsedge flowering occurs at 12 -hour photoperiod indicating that it has an intermediate flowering response to daylength (Williams 1978). However, daylength does not affect tuber formation dramatically compared to high temperatures, which stimulate tuber formation (Stroller and Sweet 1987). The survival of these tubers increases with soil depth (Stroller and Sweet 1987).

\section{Yellow Nutsedge}

Yellow nutsedge (Cyperus esculentus L.) is a herbaceous perennial weed native to North America found throughout the United States with the exception of Montana and Wyoming (Bryson and DeFelice 2009; Murphy et al. 2013; USDA 2020a). In Florida, yellow nutsedge is found from the Panhandle to the Keys (USDA 2020b). Yellow nutsedge is found within a wider geographic area compared to purple nutsedge because it is more tolerant of cold and drought (Bendixen and Nandihalli 1987).

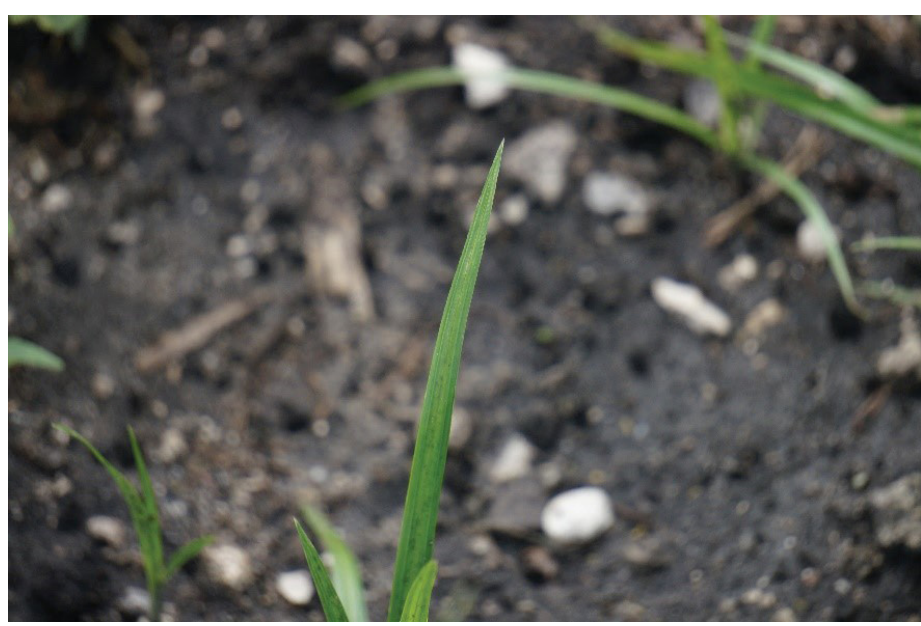

Figure 1. Purple nutsedge leaf tip. Credits: D. C. Odero, UF/IFAS

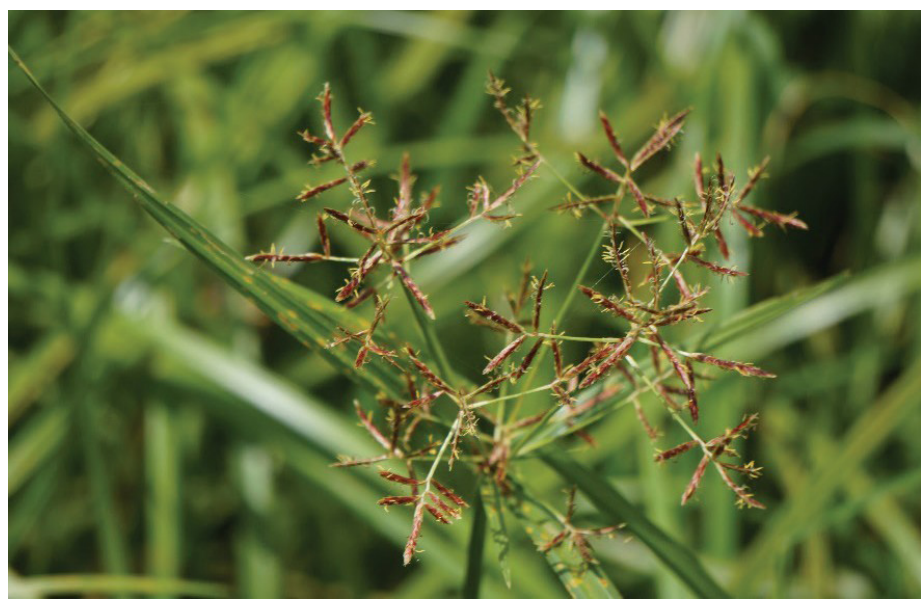

Figure 2. Purple nutsedge flower. Credits: D. C. Odero, UF/IFAS

\section{Biology and Life Cycle}

Yellow nutsedge is a rapidly spreading sedge that forms tubers at the end of the rhizomes. Similar to purple nutsedge, the seedling is small, inconspicuous, and rarely found because it also spreads almost exclusively by rhizomes and tubers. The basal leaves formed in groups of three are flat or slightly corrugated, and usually longer than the flowering stem. Leaf blades are bright green, narrow or linear, and 1/16 inch to 7/16 inch wide. The leaf tips are long and attenuated, gradually tapering to a thin, sharp point (Figure 4). The stem is triangular in cross section and 6 inches to $21 / 2$ feet tall. The flower is yellowish-brown or straw colored and formed at the end of the stem with 3 to 7 conspicuous leaves below (Figure 5). The seed is brown and less than 1/16 inch long. Tubers are round, smooth, and formed at the ends of whitish rhizomes (Figure 6). Unlike purple nutsedge, yellow nutsedge does not form groups of tubers connected by wiry chains (Figure 3 ). Propagation is primarily by tubers, and rarely by seeds (Stroller and Sweet 1987; Bendixen and Nandihalli 1987). Tuber survival increases with soil depth; they can emerge from deep in the 
soil (Figure 7) and remain viable for more than 10 years (Stroller and Sweet 1987).

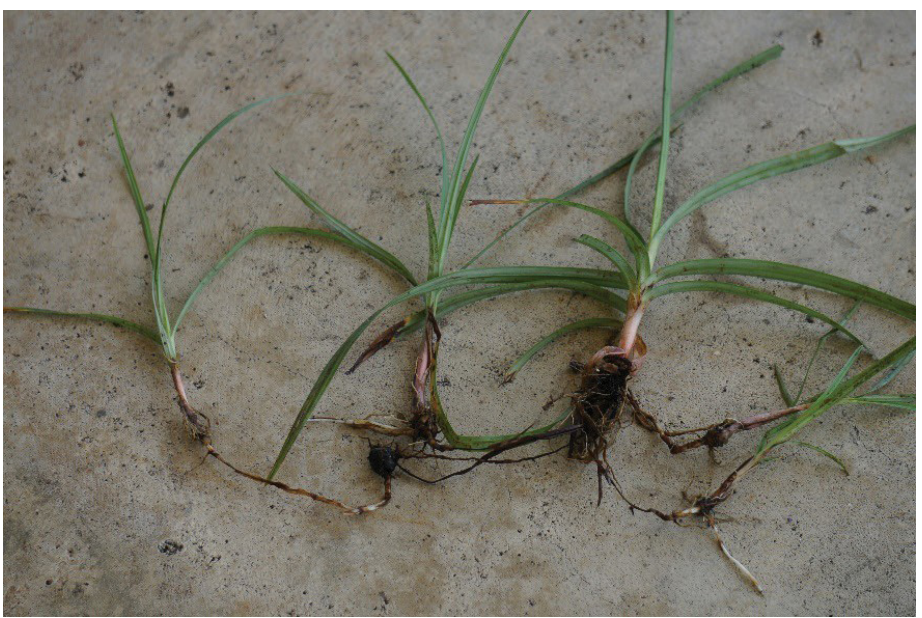

Figure 3. Purple nutsedge tubers connected by wiry rhizomes. Credits: D. C. Odero, UF/IFAS

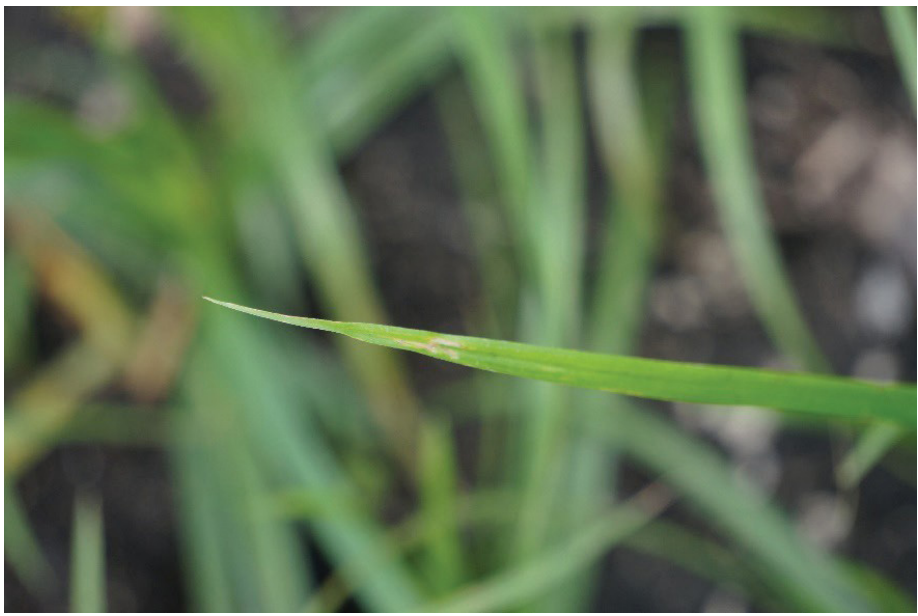

Figure 4. Yellow nutsedge leaf tip.

Credits: D. C. Odero, UF/IFAS

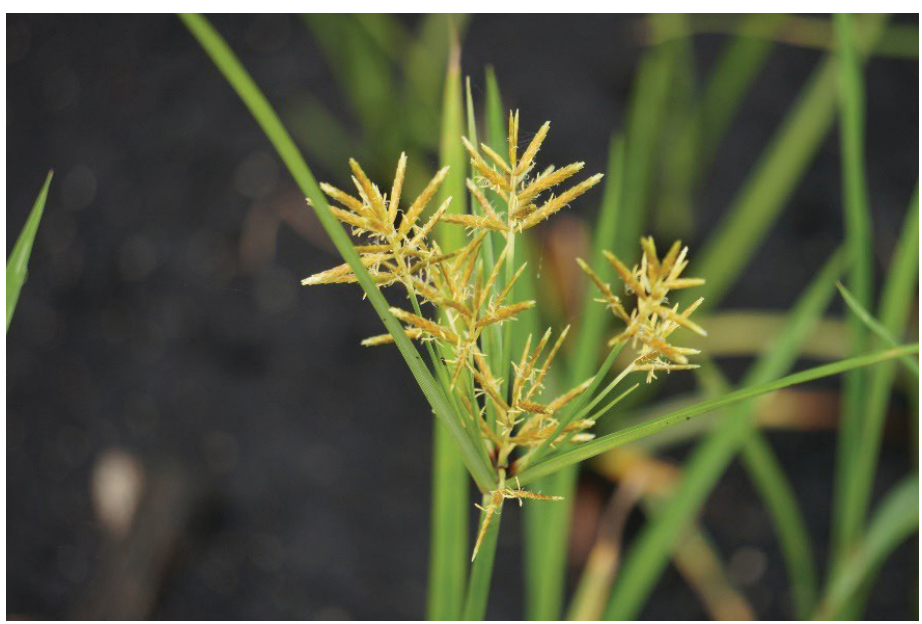

Figure 5. Yellow nutsedge flower.

Credits: D. C. Odero, UF/IFAS

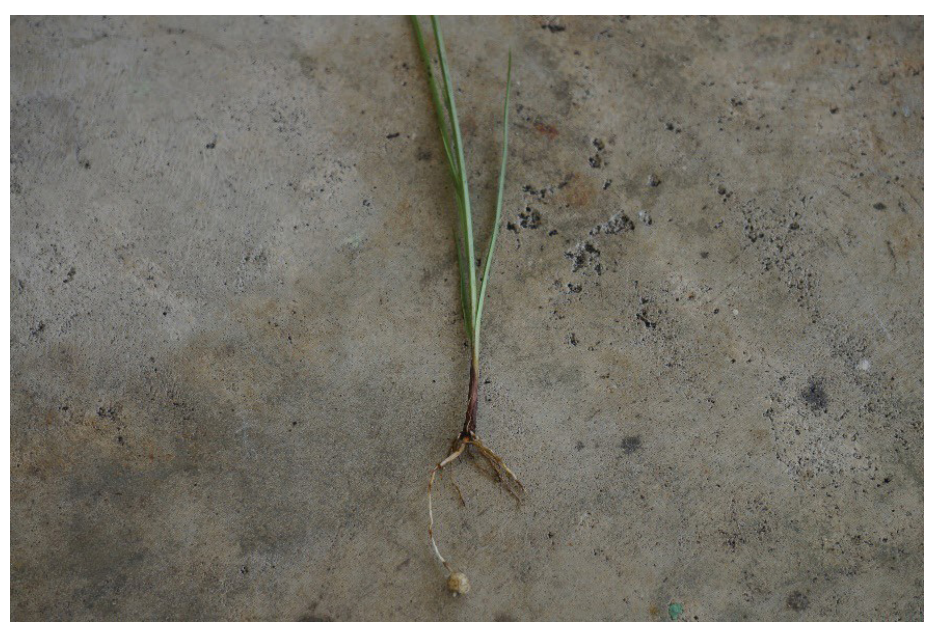

Figure 6. Yellow nutsedge tuber at the end of a rhizome.

Credits: D. C. Odero, UF/IFAS

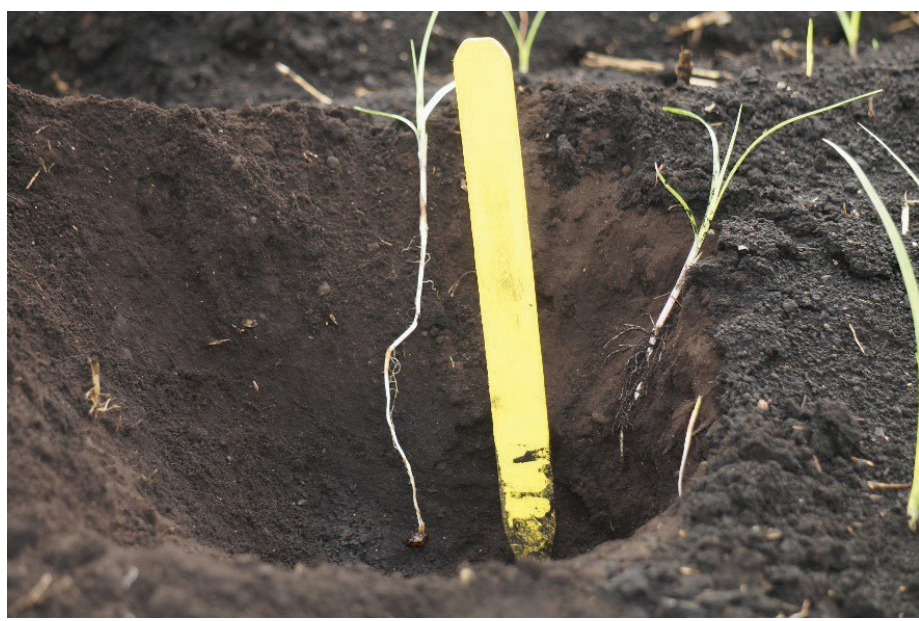

Figure 7. Yellow nutsedge emergence (on the left) from deep in the soil.

Credits: D. C. Odero, UF/IFAS

\section{Other Sedges}

Unlike the perennial growth habits that describe purple and yellow nutsedge, the annual sedge (Cyperus compressus L.), flatsedge (Cyperus odoratus L.), and rice flatsedge (Cyperus iria L.) are annual sedges. These sedge species are also commonly found in the EAA, mainly in rice fields. They do not produce tubers and propagation is by seed. Their leaves are linear and formed in groups of three, and roots are fibrous and branched. Roots of annual sedge are red, rice flatsedge roots are yellowish-red, and flatsedge roots are brown. Roots of annual sedge are also aromatic. A key characteristic to differentiate these three species is the flower or seed head. Flowers of annual sedge are clusters or flat and are greenish-white in color with toothed margins (Figure 8). Flatsedge has tan or brown flowers with 3 to 10 small and conspicuous leaves or bracts (Figure 9). Flowers of rice flatsedge are composed of elongated spikes with 3 to 7 leaflike bracts. The lowest bract is longer than the inflorescence, and spikelets of individual spikes are crowded and golden brown (Figure 10). 


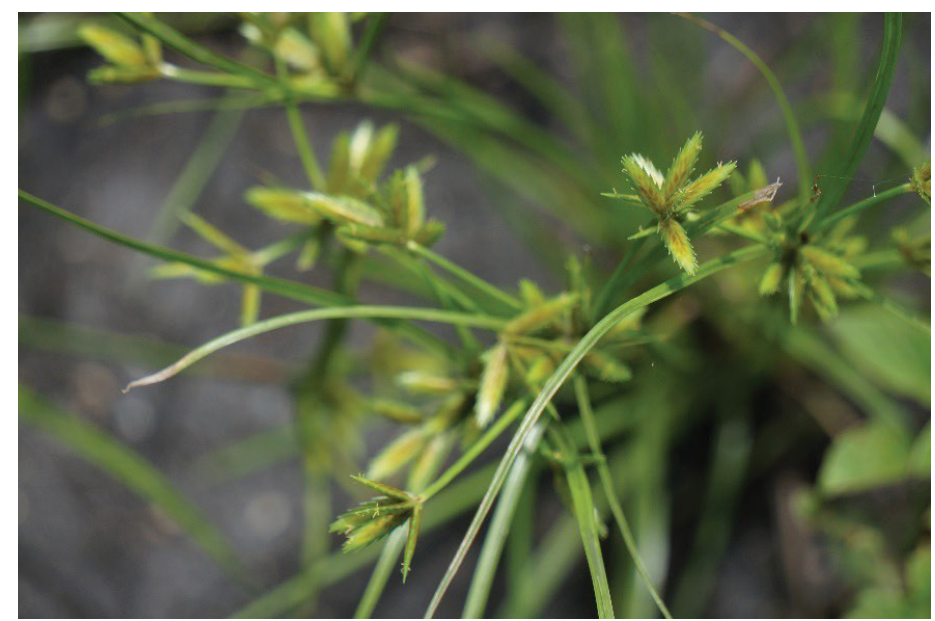

Figure 8. Annual sedge flower.

Credits: D. C. Odero, UF/IFAS

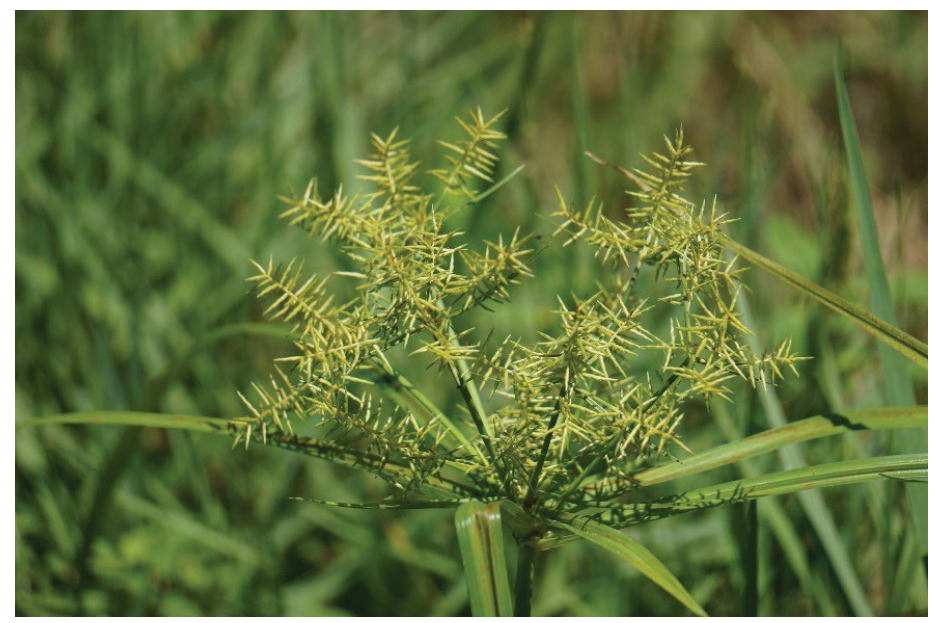

Figure 9. Flatsedge flower.

Credits: D. C. Odero, UF/IFAS

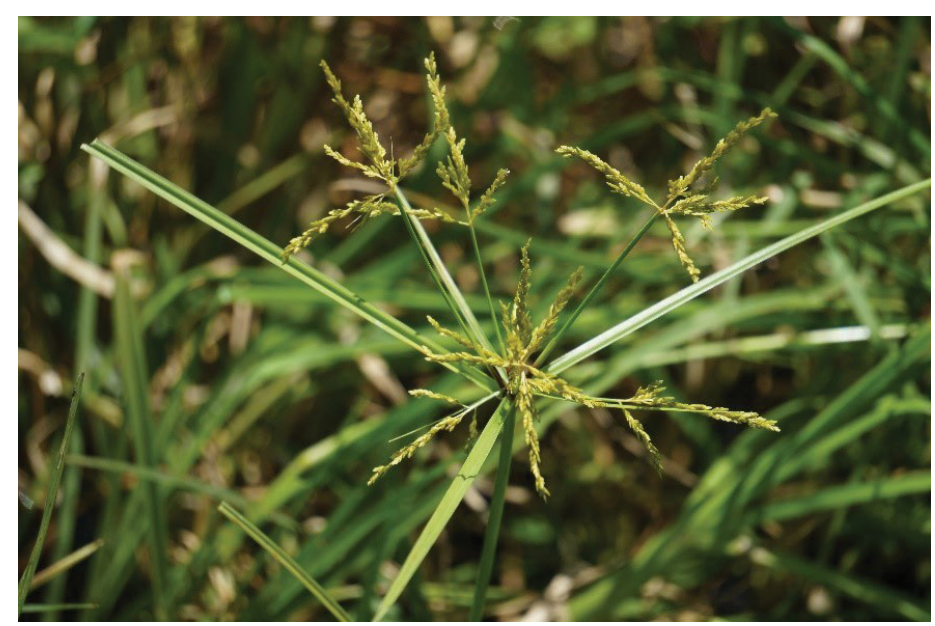

Figure 10. Rice flatsedge flower.

Credits: D. C. Odero, UF/IFAS

\section{Control of Sedges in Sugarcane and Rice}

There are a few herbicides available for control of sedges in sugarcane and rice (Table 1). These herbicides must be used in conjunction with other weed management tools such as crop rotation and cultivation to obtain maximum benefit. In addition, healthy competitive crop stands with the ability to close canopy and shade nutsedges enhance their control. The herbicides can be applied preemergence or postemergence. However, there are no preemergence herbicides for sedge control in Florida rice. Proper timing of herbicide application with respect to the growth stage of the weeds is very important. Efficacy of these herbicides on sedges will be achieved when the weeds are under 4 inches to 8 inches in height. Always read the label for the proper time of application of each herbicide.

\section{References}

Bendixen, L. B., and U. B. Nandihalli. 1987. "Worldwide Distribution of Purple and Yellow Nutsedge (Cyperus rotundus and C. esculentus)." Weed Technology 1:61-65.

Bhadha, J. H., A. L. Wright, and G. H. Snyder. 2020. Everglades Agricultural Area Soil Subsidence and Sustainability. SL 311. Gainesville: University of Florida Institute of Food and Agricultural Sciences. https://edis.ifas.ufl.edu/ss523

Bryson, C. T., and M. S. DeFelice (Eds.). 2009. Weeds of the South. Athens, GA: University of Georgia Press.

Cherry, R. H. 2017. Wireworms in Florida Sugarcane. ENY665. Gainesville: University of Florida Institute of Food and Agricultural Sciences. https://edis.ifas.ufl.edu/sc013

Etheredge, Jr., L. M., J. L. Griffin, and J. M. Boudreaux. 2010. "Purple Nutsedge (Cyperus rotundus) Competition with Sugarcane and Response to Shade." Journal of American Society of Sugar Cane Technologists 30:89-103.

Murphy, T. R., D. L. Colvin, R. Dickens, J. W. Everest, D. Hall, and L. B. McCarty. 2013. Weeds of Southern Turfgrasses. Special bulletin 31. Athens, GA: University of Georgia Extension Publications.

Rott, P., D. C. Odero, J. M. Beuzelin, R. N. Raid, M. VanWeelden, S. Swanson, and M. Mossler. 2018. Florida Crop/ Pest Profile: Sugarcane. PI-171. Gainesville: University of Florida Institute of Food and Agricultural Sciences. https:// edis.ifas.ufl.edu/pi207 
Stoller, E. W., and R. D. Sweet. 1987. "Biology and Life Cycle of Purple and Yellow Nutsedges (Cyperus rotundus and C. esculentus)." Weed Technology 1:66-73.

USDA (United States Department of Agriculture) Natural Resources Conservation Service. 2020a. "Cyperus esculentus L. Yellow Nutsedge.” Accessed December 28, 2020. https:// plants.usda.gov/core/profile? symbol=cyes

USDA (United States Department of Agriculture) Natural Resources Conservation Service. 2020b. "Cyperus rotundus L. Nutgrass.” Accessed December 28, 2020. https://plants. usda.gov/core/profile?symbol=CYRO

VanWeelden, M. T., S. Swanson, W. Davidson, M. Baltazar, and R. Rice. 2020. "Sugarcane Variety Census: Florida 2019.” Sugar Journal 83(2): 8-23.

Webster, T. M. 2012. "Weed Survey - Southern States. Grass Subsection." Proceedings of the Southern Weed Science Society 65:267-288.

Williams, R. D. 1978. "Photoperiod Effects on the Reproductive Biology of Purple Nutsedge (Cyperus rotundus)."

Weed Science 26:539-542. 
Table 1. Sedge control in sugarcane and rice. Contact: Extension weed specialist (dcodero@ufl.edu).This table lists registered pesticides that should be integrated with other pest management methods. Contact your local UF/IFAS Extension office for additional information (https://sfyl.ifas.ufl.edu/find-your-local-office).

\begin{tabular}{|c|c|c|c|c|}
\hline $\begin{array}{c}\text { Herbicide Active } \\
\text { Ingredients (Commonly } \\
\text { used products) }\end{array}$ & \begin{tabular}{c} 
HRAC MOA \\
\hline
\end{tabular} & $\begin{array}{c}\text { Application (rate and } \\
\text { total/year) }\end{array}$ & $\begin{array}{c}\text { Reentry } \\
\text { (hours) }\end{array}$ & $\begin{array}{c}\text { Weeds Controlled, Application Methods, and } \\
\text { Effectiveness }\end{array}$ \\
\hline
\end{tabular}

\section{PREEMERGENCE FOR SUGARCANE}

\begin{tabular}{|c|c|c|c|c|}
\hline $\begin{array}{l}\text { S-metolachlor + atrazine + } \\
\text { mesotrione (Lumax } 3.674 \\
\text { EZ) }\end{array}$ & $15+5+27$ & $\begin{array}{l}2.75-3.75 \mathrm{qt} / \text { acre, max. } \\
3.75 \mathrm{qt} / \mathrm{acre} \text { for PRE only } \\
\text { application }\end{array}$ & 24 hours & $\begin{array}{l}\text { Apply after new plantings, or after harvest, but prior } \\
\text { to re-emergence of ratooncane for control of yellow } \\
\text { and purple nutsedge. Higher rates should be applied } \\
\text { to organic soils. If the sedges have emerged at the } \\
\text { time of application, add a crop oil concentrate (COC) } \\
\text { at } 1 \% \mathrm{v} / \mathrm{v} \text { or a nonionic surfactant (NIS) at } 0.25 \% \mathrm{v} / \mathrm{v} \text { to } \\
\text { the spray solution. In addition to COC or NIS, a spray- } \\
\text { grade UAN (e.g., } 28-0-0 \text { ) at } 2.5 \% \mathrm{v} / \mathrm{v}(2.5 \mathrm{gal} / 100 \mathrm{gal} \\
\text { spray solution) or ammonium sulfate at } 8.5 \mathrm{lb} / 100 \mathrm{gal} \\
\text { of spray solution can be added to the spray solution. } \\
\text { Restricted Use. }\end{array}$ \\
\hline
\end{tabular}

POSTEMERGENCE FOR SUGARCANE

\begin{tabular}{|c|c|c|c|c|}
\hline $\begin{array}{l}\text { S-metolachlor + atrazine + } \\
\text { mesotrione (Lumax } 3.674 \\
\text { EZ) }\end{array}$ & $15+5+27$ & $\begin{array}{l}\text { 1.5-3.0 qt/acre. If a PRE } \\
\text { application was made } \\
\text { earlier in the season (not } \\
\text { to exceed } 3.75 \mathrm{qt} / \mathrm{acre} \text { ), } \\
\text { only } 1.5 \mathrm{qt} / \mathrm{acre} \text { may be } \\
\text { applied POST. Max. (PRE + } \\
\text { POST) } 5.25 \mathrm{qt} / \mathrm{acre}\end{array}$ & 24 hours & $\begin{array}{l}\text { Can be applied POST for yellow and purple nutsedge } \\
\text { before sugarcane reaches } 60 \text { inches in height. It should } \\
\text { be applied to actively growing weeds. If sedges have } \\
\text { emerged at the time of application, add adjuvants at } \\
\text { rates similar to PRE application. Restricted Use. }\end{array}$ \\
\hline $\begin{array}{l}\text { Trifloxysulfuron (Envoke } \\
75 \text { DG) }\end{array}$ & 2 & $\begin{array}{l}0.3-0.6 \text { oz/acre, max. } 1.5 \\
\text { oz/acre }\end{array}$ & 12 hours & $\begin{array}{l}\text { Provides good control of yellow and purple nutsedge. } \\
\text { Apply POST ( } 0.3 \text { oz/acre) on pre-spiking to spiking } \\
\text { plant cane when sedges are less than } 4 \text { to } 6 \text { inches } \\
\text { in height. Apply POST over-the-top on ratoon cane } \\
\text { or POST-directed on both plant and ratoon cane. } \\
\text { POST over-the-top ( } 0.3 \text { oz/acre) can be applied until } \\
\text { sugarcane reaches } 24 \text { inches in height in ratoon cane. } \\
\text { POST-directed applications ( } 0.3-0.6 \text { oz/acre) can be } \\
\text { made on plant and ratoon cane that is } 24 \text { inches tall } \\
\text { through layby. Applications cannot be more than } 3 \\
\text { per season. Apply with NIS at } 0.25 \% \mathrm{v} / \mathrm{v} \text { and COC at } \\
0.5-1.0 \% \mathrm{v} / \mathrm{V} \text {. COC may be used ONLY when applying } \\
\text { POST-directed. Refer to the label for tank-mix options. }\end{array}$ \\
\hline $\begin{array}{l}\text { Halosulfuron-methyl } \\
\text { (Sandea } 75 \% \text { DF) }\end{array}$ & 2 & $\begin{array}{l}0.75-1.33 \text { oz/acre, max. } \\
2.67 \text { oz/acre }\end{array}$ & 12 hours & $\begin{array}{l}\text { Can be applied at any stage of sugarcane growth for } \\
\text { control of yellow and purple nutsedge. No more than } \\
3 \text { applications (including PRE applications) may be } \\
\text { made. Apply to emerged nutsedge after nutsedge } \\
\text { has reached 3- to } 8 \text {-leaf stage. Add COC at } 1 \% \mathrm{v} / \mathrm{v} \text { or } \\
\text { NIS } 0.25-0.50 \% \mathrm{v} / \mathrm{v} \text {. Applications should be made to } \\
\text { actively growing weeds. }\end{array}$ \\
\hline $\begin{array}{l}\text { Halosulfuron-methyl } \\
\text { + dicamba (Yukon } 67.5 \\
\text { WSG) }\end{array}$ & $2+4$ & $\begin{array}{l}\text { 4-8 oz/acre, max. } 8 \text { oz/ } \\
\text { acre }\end{array}$ & 24 hours & $\begin{array}{l}\text { May be applied to any stage of sugarcane growth } \\
\text { for control of yellow and purple nutsedge. Apply to } \\
\text { emerged nutsedge after sedge has reached } 3 \text { - to } \\
\text { 8-leaf stage. Do not make more than } 2 \text { applications } \\
\text { per growing season. Take care to prevent spray drift to } \\
\text { sensitive crops and consult the Florida Organo-Auxin } \\
\text { Herbicide Rule prior to application. Add COC at } 1 \% \mathrm{v} / \mathrm{v} \\
\text { or NIS at } 0.25-0.50 \% \mathrm{v} / \mathrm{v} \text {. Applications should be made } \\
\text { to actively growing weeds. }\end{array}$ \\
\hline
\end{tabular}




\begin{tabular}{|c|c|c|c|c|}
\hline $\begin{array}{l}\text { Herbicide Active } \\
\text { Ingredients (Commonly } \\
\text { used products) }\end{array}$ & HRAC MOA & $\begin{array}{c}\text { Application (rate and } \\
\text { total/year) }\end{array}$ & $\begin{array}{l}\text { Reentry } \\
\text { (hours) }\end{array}$ & $\begin{array}{c}\text { Weeds Controlled, Application Methods, and } \\
\text { Effectiveness } \\
\text { (see product label for details) }\end{array}$ \\
\hline \multicolumn{5}{|c|}{ POSTEMERGENCE FOR RICE } \\
\hline Bentazon (Basagran $4 \mathrm{~L}$ ) & 6 & $\begin{array}{l}1.5-2.0 \mathrm{pt} / \mathrm{acre}, \max .4 \mathrm{pt} / \\
\text { acre }\end{array}$ & 48 hours & $\begin{array}{l}\text { Best control of sedges is achieved with early } \\
\text { application. Yellow nutsedge (4- to 6-leaf) may be } \\
\text { controlled with the lower rate. Higher rates are needed } \\
\text { for larger yellow nutsedge. Refer to the label for tank- } \\
\text { mix options. }\end{array}$ \\
\hline $\begin{array}{l}\text { Bensulfuron-methyl } \\
\text { (Londax 60\% DF) }\end{array}$ & 2 & $\begin{array}{l}0.5-1.0 \text { oz/acre, } \max .1 .67 \\
\text { oz/acre }\end{array}$ & 24 hours & $\begin{array}{l}\text { Best control is achieved when applied early POST to } \\
\text { small, actively growing sedges. Can be applied to } \\
\text { flooded rice; see label for specific requirements. Refer } \\
\text { to the label for tank-mix options. }\end{array}$ \\
\hline $\begin{array}{l}\text { Halosulfuron-methyl } \\
\text { (Sandea 75\% DF) }\end{array}$ & 2 & $\begin{array}{l}0.67-1.33 \text { oz/acre, max. } \\
1.67 \text { oz/acre }\end{array}$ & 12 hours & $\begin{array}{l}\text { Provides control of annual sedges, purple and yellow } \\
\text { nutsedges. Can be applied after rice emergence to } 48 \\
\text { days before harvest. Use } 0.67 \mathrm{oz} / \mathrm{acre} \text { for nutsedges } \\
\text { less than } 6 \text { inches tall and } 1-1.33 \mathrm{oz} / \mathrm{acre} \text { for nutsedges } \\
6 \text { to } 12 \text { inches tall. Add NIS at } 0.25-0.50 \% \mathrm{v} / \mathrm{v} \text { or COC at } \\
1.0 \% \mathrm{v} / \mathrm{v} \text {. Refer to the label for tank-mix options. }\end{array}$ \\
\hline Penoxsulam (Grasp 2 EC) & 2 & $\begin{array}{l}2.0-2.8 \mathrm{fl} \text { oz/acre, max. } 5.6 \\
\text { fl oz/acre }\end{array}$ & 12 hours & $\begin{array}{l}\text { Provides control of annual sedges. Apply at 2- to 3-leaf } \\
\text { stage rice or after } 1 / 2 \text {-inch internode elongation stage } \\
\text { of rice. Do not make more than } 2 \text { applications per } \\
\text { season. Add a COC or methylated seed oil (MSO) at 1\% } \\
\text { v/v. Flooding should be delayed for } 3 \text { days following } \\
\text { application. }\end{array}$ \\
\hline $\begin{array}{l}\text { Penoxsulam + triclopyr } \\
\text { (Grasp Xtra 2.31 EC) }\end{array}$ & $2+4$ & $\begin{array}{l}16-22 \mathrm{fl} \text { oz/acre, } \max .22 \mathrm{fl} \\
\text { oz/acre }\end{array}$ & 24 hours & $\begin{array}{l}\text { Provides control of annual sedges. Apply at 2- to 3-leaf } \\
\text { stage rice or after } 1 / 2 \text {-inch internode elongation stage } \\
\text { of rice. Add a COC or MSO at } 1 \% \text { v/v. Flooding should } \\
\text { be delayed for } 3 \text { days following application. }\end{array}$ \\
\hline
\end{tabular}

